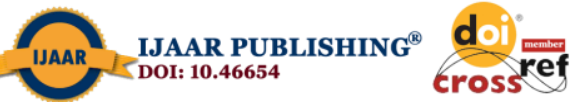

International Journal of Advanced Academic Research (Arts, Humanities and Education) | ISSN: 2488-9849 Vol. 5, Issue 8 (August, 2019) | www.ijaar.org

\title{
THE RELEVANCE OF ISLAMIC SYSTEM OF WILLS AND INHERITANCE FOR POVERTY ALLEVIATION AND THE RESPONSE OF MUSLIMS IN OYO TOWN
}

\author{
YUSUF M. G. \\ Islamic Studies Department, \\ The College of Education, Lanlate, \\ Oyo State, Nigeria.
}

\begin{abstract}
Poverty has remained part of human life, but more persistently it has affected underdeveloped nations like Nigeria. In Nigeria and most especially Oyo state, various approaches have been and are still being adopted to remove the ravaging scourge of poverty, but many more are yet to be adopted, One of such strategy is the principles of Islamic wills and inheritance. This paper therefore examines its policy of fair share and testator's freedom to dispense a third of his estate for humanitarian services as a vital tool in poverty eradication programs. The paper reveals that many Muslims in Oyo state have not adequately utilized the balanced principles of Islamic wills and inheritance to cater for their heirs and other people. The Paper then recommends among others that people should endeavour to use their wealth to help the poor while they are still alive, and that rich testators whose heir are equally rich should use a third of their estate to contribute to poverty eradication programs in the society.
\end{abstract}

Keywords: Islamic System, Wills, Inheritance rights in Islam, Poverty, Poverty Alleviation. 


\section{Introduction}

Poverty has remained part of human existence. But its scourge, manifestations and consequences has dealt more blows to many underdeveloped nations of the world. This scourge has not eluded Nigeria and Oyo State in particular. For the past three decades, incidence of poverty has risen above seventy percent (Ajakaiye \& Adeleye, 2001). This according to Adeniji (2006) is unimaginable considering the wealth and endowment of the nation.

Many factors has been alluded as causes of poverty in Nigeria, but the main task of this paper is to examine the culturally induced poverty among Muslims in Oyo State with particular focus on aspects of will and inheritance rights. It is not a gainsaying that many Muslims in the state are poor despite having claim to valuable estates. Many have abandoned properties like farm lands, orchards, houses and other properties belonging to their deceased parents due to lack of proper regulation and crisis culminating from attempts to claim their rights. In the same vein, many women and children have been unjustly disinherited, thereby increasing their suffering and plunging them into state of poverty (Adeniji, 2002).

In another dimension, lack of properly documented wills have kept many heirs ignorant of existing estates of their parents and added to this is the failure of testator's freedom to will his property as he wills. Records have shown instances of men who will their entire properties or larger percentages of their properties to women friends and other categories of non-legal heirs thereby leaving their heirs in perpetual experiences of poverty. The objective of this work therefore is to examine the potency of Islamic wills and inheritance law in ameliorating the scourge of poverty in Oyo State.

\section{Theoretical Framework}

It is essential at this juncture to discuss various concepts involved in this discourse. Such concepts include 'poverty', 'wills' and 'inheritance rights in Islam'. This becomes worthwhile for proper assessment of manifestations of poverty among Muslims in Oyo State. Aside this, the section will equally address the cultural practices of will and inheritance among Muslims in Oyo State.

\section{Poverty and its Manifestations among Muslims in Oyo State}

The word "poverty" according to Fishlow (1995) is of two origins; old French "poverte" and latin "pauper" meaning "poor". It is obvious that a standard definition of the word poverty is difficult to arrive at because of its multidimensional nature. Poverty, as commonly defined is a situation of low income or low consumption. It can be further viewed as a situation in which individuals are unable to meet their necessities of life. This is why Fishlow (1995) describes poverty as "a situation of being very poor". Ajakaiye and Adeleye (2001) consider poverty as a function of education, health, child mortality and other demographic values. To the two scholars, poverty is the availability or otherwise of the above parameters.

Adeniji (2006) says that poverty can either be absolute or relative. He describes the absolute poverty as a situation where the resources of individuals or families are inadequate to provide their basic needs of life such as food, shelter, clothing etc. while for the relative poverty is a situation of individual household compared with the average income in the country which varies with the level of average income. 
The high rate of poverty in Nigeria and Oyo state in particular is an irony considering the wealth and natural endowment of the nation. Poverty statistics shows the rising incidence of poverty for the past two decades. From 27 percent in 1996 and rose to 46 percent in 1985. It declined to 43 percent in 1992 and rises again to 66 percent in 1996 and 1999, poverty incidence is said to be more than 70 percent in 1996 and 1999, poverty incidence is said to be more than 70 percent. In the year 2005, poverty incidence in Nigeria had declined to 54 percent (Fishlow, 1995). However, the latest figure is still considered, considering the population growth. Furthermore, decline in productive activities, lack of access to social services, neglect and stagnant agricultural production, weak industrial sector, high rate of unemployment, high rate of corruption and the mismanagement of Nigeria economy all combine to aggravate the incidence and depth of poverty in Nigeria. The country is lacking behind in term of measuring the quality of life available to the populace. Data also shows that poverty is more intense in the rural areas that the urban areas. In 1985, the incidence of poverty in the urban areas was 37 percent, while that of the rural areas was 51.4 percent. In 1992, urban was 37.5 percent while the rural was 69.3 percent. As at 2004, poverty incidence in the urban area was 43.1 percent, while that of the rural was 63.8 percent (NBS 2005). The implication of the above data is that poverty in Nigeria is a rural as well as urban phenomenon.

\section{Causes of Poverty in Nigeria}

Fishlow (1995) identified many causes of poverty in sub-saharan Africa, among which are:

- Inadequate access to employment opportunities;

- Inadequate physical assets, such as land, capital, minimal access by the poor to credits even on small scale;

- Inadequate access to markets where the poor can sell goods and services;

- Inadequate access to means of supporting moral development in poor regions;

- Low endowment in human capital;

- Destruction of rural resources leading to environmental degradation and reduced productivity.

- Inadequate access to the assistance for those living at the margin and those victimized by transiting poverty;

- Lack of participation, that is, failure to draw the poor into the design of developmental programs.

It is in line with this that the principle of fair share of inheritance and regulation of will law in Islam are considered as effective poverty alleviation strategy. The principles if adopted could provide funds for heirs and other people in the society upon the death of a deceased.

\section{Wills and Inheritance Practice among the People of Oyo Town}

A will is a document by which a person directs his or her estate to be distributed upon death (Ehijeagbon, 2002). It is a testamentary and revocable document voluntarily made, executed and witnessed according to law by a testator with sound disposing mind wherein he 
disposes his property subject to any limitation imposed by law and wherein he gives such other directives as he may deem fit to his personal representatives, otherwise known as his executors, who administer his estate in accordance with the wishes manifested in the will (Abid, 2012).

The use of will in the administration of inheritance is a global practice. In England, testamentary freedom is allowed and is in theory unrestricted. That is, the testator is allowed complete freedom to dispose his property in any way or manner he chooses... (Abid, 2012). This law has remained manifest in Nigeria's will and inheritance laws. Meanwhile customary constraints have also shaped the practice. For example, the Yoruba system of wills which is practiced in Oyo town and inheritance according to Adeniji (2002), appears as follows:

All the members of the family would be around to distribute the clothes, trinkets, houses, furniture, etc. The property to be shared among the heirs would be laid down and two elders would come out to pray and admonish the relatives and children of the deceased. The children of the deceased would all sit together according to maternal lines. The productive wives would be seated with their children but the wife who did not give birth to any child for the deceased would have no share because they do not give share to wife but children of the deceased.

A wife may give birth to ten children, the second wife may give birth to four while the third wife may give birth to only one child. The property would be divided into three equal parts because; a thigh is not more than a thigh. One of the elders would come out to the middle to divide the property of the deceased in such a way that they would all be equal. Another elder would come out to ascertain that the property was equally distributed and free of partiality. The most senior child of the first wife would come out to take the share that belongs to his brothers and sisters, followed by the oldest child of the second wife and lastly by oldest child of the third wife. All these children would express their gratitude to the elders present by weeping. The elders would still inquire from the children to express their views about the distribution so as to prevent misunderstanding among the children. If there is, the elders would explain how it was so but these elders do not revert decision so as not to cause any quarrel.

In case of a stalemate in the distribution, a masquerade would appear to do the distribution and what it does is the final. The adherents of Yoruba Traditional Religion believe that the masquerade has come from heaven as the final arbiter. Any child of the deceased who refuses to abide by the verdict of the masquerade would die instantly (Adeniji, 2002).

Meanwhile if the deceased has given a specific function as to how his property would be distributed before his death, his wish would be carried out. But as time passed, this absolute freedom was abused by many testators. Many dependants were dis-inherited based on the Will Acts. This then led to promulgation of the Inheritance (Family Provision) Act 1938. This Act gave the courts a limited power to override the deceased's testamentary provisions by ordering provision to be made out of a man's estate for the maintenance of his widow and a limited category of other dependants (Nwogugu, 1990). 


\section{Wills Under Islamic Law}

The Islamic Will is called Wasiyya. Literally, Wasiyya means "Command" or "Obligation". Technically in the Shariah, Wasiyya is a set of instructions given by a person to individuals whom he accepts to survive him (Abid H., 2012). The making of a will is a religious obligation binding on all adult Muslims who have properties.

The Quran recommends thus:

It is prescribed for you, when death approaches any of you, if he lives wealth, that he makes to parents and next of kin, according to reasonable manners. This is a duty upon the pious-God fearing (Q2:180).

This is further buttressed by a tradition of the Prophet:

It is not proper for a Muslim who has something to bequeath to sleep two consecutive nights without having his will written with him (Maulana M.A.; 2002).

\section{The Scope of Wills in Islam}

Wasiyyah is not confined to a mere allocation of properties to non-legal heirs. According to Abid (2012), Wasiyyah has a very wide scope. It includes Islamic Instructions and admonition, monetary distribution and assignment of rights. It can also be used to recommend the discharge of trust (Amanah) repose in one.

\section{Essential of a Valid Will and Inheritance in Islam}

There are some basic conditions which must be fulfilled in the writing of a will in Islam. Such conditions according to Abid (2012) include the following;

Adulthood: Every adult Muslim with reasoning ability has the duty to make a will. This is very similar to the provisions in the statutory law of Nigeria which stipulates that a person must be at least 21 before making a will.

Soundness of Mind: The testator under Islamic law is expected to have the legal capacity to dispose whatever he bequeaths in his will. When making a will, he must be of sound mind. He must not act under any compulsion and he must understand the provisions of Sharia on the administration of inheritance. Apart from being the rightful owner of his property, he must be prepared to act in line with the dictates of Islam.

Religious Status: The principles guiding wills and inheritance in Islam is binding on all Muslims (Q2:180). Its acceptability and practice is a religious rite. No one is expected to force it upon the adherents of other religions. However, a non-Muslim is allowed to adopt the Islamic Wills in the distribution of his estates if he wills. In that regard, his action is based on his personal choice and not his religious duty. Mirath on the other hand means inheritance to be divided from the property of the deceased among his successors (Adeniji 2002).

It is also pertinent to state at this juncture that a Muslim does not die intestate. Will must not extend beyond one-third of a testator's property, and its allocation is only for nonlegal heirs (Maulana, 2002). The portion of inheritance to legal heirs has been ordained in the Quran, and no one is expected to impose his limited knowledge over the unbounded knowledge of Allah. 
The Quran ordained it thus:

From what is left by parents and those nearest related, there is a share for men and a share for women, whether the property be large or small. A share made compulsory. (4:7).

Later on the Law of Inheritance was put in the following Qur'anic verses:

Allah has thus enjoyed you concerning your children: A male shall inherit twice as a female. If there are more than two girls, they shall inherit in the half. As for his parents, each of them shall have the sixth of he left, if he has a child but if he has no child and only his two parents inherit him, then his mother shall have the third but if he has brothers, then his mother shall have the sixth after the payment of any bequest he may have bequeathed or a debt. You may wonder whether your parents or your children are morebeneficial to you. But this is the law of Allah: He is wise and All-knowing.You shall have half of what your wives leave if They have no child, but if they have a child, then you shall have a fourth of what they leave if you have no child, but if you have a child then they shall have the eight of what you leave after payment of nay bequest you may have bequeathed or a debt: and if a man or woman having no children's leaves inheritance and he (or/she) has a brother or a sister, then each of these two shall have the sixth, but if they are more than that they shall be sharers in the third after payments of any bequest than may have been bequeathed or a debt that doe not harm others. That is a communication from Allah. He is Gracious and all-knowing Q4:11:12.

Looking critically at these verses one will observe that:

(a) The husband or wife was made an heir.

(b) Females and cognates were made competent to inherit

(c) The brothers and the sisters can inherit if the deceased has no child.

(d) The bequest and the debt must be paid before the distribution of the property. 
(e) Parents and ascendants were given one half to inherit.

(f) As a general rule, a female was given one half of the share of a male.

From the foregoing, one could deduce the following as the basic ingredients of poverty alleviation as far as Islamic wills and inheritance is concerned.

\section{Objectives of the Study}

The general objective of this study is to examine Muslim awareness of the relevance of Islamic System of wills and inheritance in poverty alleviation in Oyo town.

Specifically, the study will examine the following;

1. To examine Muslims' awareness of factors that cause poverty in Oyo town.

2. To Examine Oyo Muslims' awareness of different forms of wills and inheritance system in their domain.

3. To assess Muslims' awareness of the methods of wills and inheritance under Islamic Law.

4. To analyse Muslims' awareness of the potency of Islamic wills and inheritance for poverty alleviation.

\section{Research Questions}

The following questions are thus generated from the study;

1. Are the Muslims in Oyo familiar with the factors that cause poverty in their area?

2. Are the Muslims in Oyo aware of different forms of wills and inheritance among them?

3. Are the Muslims in Oyo informed about the system of wills and inheritance under potency of Islamic wills and inheritance for poverty alleviation?

\section{Research Design and Procedure}

The study is a survey aimed at finding out the Muslims awareness about the relevance of Islamic system of wills and inheritance in poverty alleviation in Oyo state. The population consisted of 1600 (approximately) Muslims selected from four Local Government Areas in Oyo Town. The Local Government Areas include, Oyo East, Oyo West, Atiba Local Government and Afijio Local Government. Four hundred questionnaires were administered on samples from each of the local government.

Samples were drawn from Muslim population in popular Central Mosques in each of the Local Government. The sampling was carried out in this order.

\begin{tabular}{|l|c|c|c|}
\hline Local Government & Number of Mosques & \multicolumn{2}{|c|}{ Sample } \\
\hline Oyo East Local Government & 05 & 200 & 200 \\
\hline Oyo West Local Government & 05 & 200 & 200 \\
\hline Atiba Local Government & 05 & 200 & 200 \\
\hline Afijio Local Government & 05 & 200 & 200 \\
\hline Grand Total & 20 & 800 & 800 \\
\hline
\end{tabular}

\section{Instrumentation}

A researcher-designed 18 items questionnaire was designed to elicit responses from the respondents to examine their awareness about the potency of Islamic system of wills and inheritance in poverty alleviation in Oyo Town. The questionnaire was validated by four Chief Lecturers of Islamic Studies from the Federal College of Education, Oyo and Emmanuel Alayande College of Education, Oyo. 


\section{Analysis of Data}

The analysis of data gathered reveals the following wills and inheritance related.

Table 1: Muslims Awareness of Factors that Cause Poverty in Oyo Town

\begin{tabular}{|l|l|l|l|l|l|}
\hline S/N & \multicolumn{1}{|c|}{ QUESTION } & YES & $\begin{array}{l}\text { \% } \\
\text { YES }\end{array}$ & NO & $\begin{array}{l}\text { \% } \\
\text { NO }\end{array}$ \\
\hline 1. & $\begin{array}{l}\text { Lack of accessibility to land and other inheritance } \\
\text { properties causes poverty }\end{array}$ & 1300 & 81.25 & 300 & 18.75 \\
\hline 2. & $\begin{array}{l}\text { Low endowment in human capital aggravates } \\
\text { poverty. }\end{array}$ & 1200 & 75 & 400 & 25 \\
\hline 3. & $\begin{array}{l}\text { Destruction of rural resources leads to degradation } \\
\text { and causes poverty. }\end{array}$ & 900 & 56.25 & 700 & 43.75 \\
\hline 4. & $\begin{array}{l}\text { If lack of assistance from wealthy distant relatives } \\
\text { aggravate poverty. }\end{array}$ & 1020 & 63.75 & 580 & 36.25 \\
\hline
\end{tabular}

Table 2: On Muslims' awareness of traditional form of wills and inheritance system in Oyo Town.

\begin{tabular}{|l|l|l|l|l|l|}
\hline S/N & \multicolumn{1}{|c|}{ QUESTION } & YES & $\begin{array}{l}\text { \% } \\
\text { YES }\end{array}$ & NO & $\begin{array}{l}\% \\
\text { NO }\end{array}$ \\
\hline 1. & $\begin{array}{l}\text { Under traditional custom, every member of the } \\
\text { family participate in inheritance meeting }\end{array}$ & 1000 & 62.5 & 600 & 37.95 \\
\hline 2. & $\begin{array}{l}\text { The responsibility of distribution devolve on the } \\
\text { elders }\end{array}$ & 1200 & 75 & 400 & 25 \\
\hline 3. & $\begin{array}{l}\text { Wives are exempted from deceased husbands } \\
\text { estate }\end{array}$ & 1250 & 78.125 & 350 & 21.87 \\
\hline 4. & $\begin{array}{l}\text { The estate is distributed to children according to } \\
\text { number of wives (Idi-Igi) }\end{array}$ & 1250 & 78.125 & 350 & 21.875 \\
\hline 5. & $\begin{array}{l}\text { A mother with more children is usually the most } \\
\text { favored. }\end{array}$ & 1150 & 71.875 & 450 & 28.125 \\
\hline 6. & $\begin{array}{l}\text { In case of stalemate, a masquerade is summoned } \\
\text { to administer final distribution. }\end{array}$ & 1150 & 71.875 & 450 & 28.125 \\
\hline 8. & $\begin{array}{l}\text { Sometimes, the deceased's instructions are } \\
\text { adopted while sharing the estate. }\end{array}$ & 100 & 62.5 & 600 & 37.95 \\
\hline
\end{tabular}

Table 3: On Muslims' awareness of the methods of wills and inheritance under Islamic Law.

\begin{tabular}{|l|l|l|l|l|l|}
\hline S/N & \multicolumn{1}{|c|}{ QUESTION } & YES & $\begin{array}{l}\text { \% } \\
\text { YES }\end{array}$ & NO & $\begin{array}{l}\text { \% } \\
\text { NO }\end{array}$ \\
\hline 1. & $\begin{array}{l}\text { Wassiyya is a set of instruction given by a person } \\
\text { to his or her survivors }\end{array}$ & 1020 & 63.75 & 580 & 36.25 \\
\hline 2. & $\begin{array}{l}\text { Muslims are expected to write a will on any } \\
\text { property within two days of possession. }\end{array}$ & 1200 & 75 & 400 & 25 \\
\hline 3. & $\begin{array}{l}\text { Wills should not exceed one-third of the estate. } \\
\text { The rest is to be shared according to Quranic } \\
\text { prescription. }\end{array}$ & 1400 & 87.5 & 200 & 12.95 \\
\hline 4. & $\begin{array}{l}\text { Wills also includes instructions, admonitions and } \\
\text { assignment of rights. }\end{array}$ & 1300 & 81.25 & 300 & 18.75 \\
\hline 5. & Only adults can write a will & & & & \\
\hline
\end{tabular}


Table 4: Muslim's awareness of the potency of Islamic wills and inheritance for poverty alleviation.

\begin{tabular}{|l|l|l|l|l|l|}
\hline S/N & \multicolumn{1}{|c|}{ QUESTION } & YES & $\begin{array}{l}\text { \% } \\
\text { YES }\end{array}$ & NO & $\begin{array}{l}\text { \% } \\
\text { NO }\end{array}$ \\
\hline 1. & $\begin{array}{l}\text { The limit of 1/3 placed on wills checkmates } \\
\text { arbitrary act of disinheriting legal heirs. }\end{array}$ & 140 & 87.5 & 200 & 12.95 \\
\hline 2. & $\begin{array}{l}\text { Adequate record-keeping imposed by Islamic will } \\
\text { safeguards rights of beneficiary, it is helpful in } \\
\text { poverty alleviation. }\end{array}$ & 1500 & 93.75 & 100 & 6.25 \\
\hline 3. & $\begin{array}{l}\text { Freedom (under Islamic Law) to will properties to } \\
\text { the poor non-legal heir will contribute to poverty } \\
\text { alleviation scheme. }\end{array}$ & $\begin{array}{l}\text { Assurance of non-discriminatory fair share (under } \\
\text { Islamic system of wills and inheritance is a } \\
\text { catalyst for poverty alleviation). }\end{array}$ & 7230.125 & 250 & 21.875 \\
\hline 4.875 & 370 & 23.125 \\
\hline
\end{tabular}

\section{Discussion}

Findings from this study reveal that Muslims are aware of the following facts about wills and inheritance under Islamic Law.

\section{The limitations of Islamic Wills as a Check on Testator}

The arbitrary act of testator to render his inheritors poor is checked by the limitations placed on the use of wills in Islam. In Islam, the testator is not at liberty to apportion his property according to his wishes and preferences. He is not at liberty to will his property to his 'strayed dog', a mistress and even to a charitable program at the detriment of his heirs whose portions have been ordained in the Quran. The duty of a testator to be fair and just is so wide and onerous so much so that he is not to allow the enmity of his spouse or any other heirs to deter him from the right part. Even if he is dissatisfied with any acts on their part, he is expected to imbibe the spirit of forgiveness and leave all judgments to Allah.

\section{Prevention of Discriminatory Tendencies}

Islamic provisions on will and inheritance will also prevent economic deprivation which usually arises due to non availability of adequate records. When the testator properly document how he wants a third of his estate to be shared, it becomes impossible to deprive the beneficiaries of rights to such an estate.

\section{Opportunity to contribute to Poverty Alleviation Scheme}

The testator is able to use part of his property to assist others. For instance, he may apportion part of it as bequest to continue to assist people who depended on him during his life time. The apportionment could be in form of endowment or outright pay-off to such beneficiaries. The bequest may also be used to cater for the poor, orphans, widows and other less-privileged people who are close to him but fall outside the category of his legal heirs.

\section{Classification of Nature and Status of Property}

The testator is also enabled to clarify the nature and condition of the estate. Manipulation and tampering of such estate is thus prevented through a will. In addition to this, he is equally afforded the opportunity to give clarification on ownership of all properties within his custody. For example, properties he jointly owned with his wife or any other business partner(s) are quickly identified and apportioned to rightful owners. The deceased's 
loans are also promptly repaid. Many people are usually thrown into state of poverty due to lack of straight legal records to authenticate their claims.

\section{Assurance of Fair Share among Legal Heirs}

There is fair and balanced share of inheritance among heirs when Islamic system of inheritance is adopted. Males are generally apportioned twice the share of females in order to equip them to fulfill their responsibilities as financiers and maintainers of females. Women are also apportioned rights to inheritance. They are not to be dis-inherited and left to wallow in poverty. Females are to inherit in various dimensions as wives, daughters, sisters, mothers, and grandmothers. The onus is to accord them the right to own properties and thus become free from poverty.

\section{Conclusion and Recommendations}

From the foregoing, one could easily deduce that the principle of wills and inheritance in Islam is not only meant to guide the wishes of the deceased, but also contains a direction to Muslims to prevent obvious inequality inherent in many other system of inheritance. It is also meant to help in ameliorating the scourge of poverty in the society. It is therefore pertinent to give the following recommendations.

Muslims should endeavour to learn the basic principles of Islamic Law of wills and inheritance and adopt it as a binding principle and compulsory rite of Islam. Muslims living in states where Shariah is practiced should write self proven wills with specifications to appoint knowledgeable and dependable Islamic scholars (as executors) to administer their estate in line with Islamic principles. Muslims should imbibe the spirit of providing for the less privileged in the society. It is better to give alms in one's lifetime than to entrust it to one's inheritors.

It is also important for heirs to work hard to earn a living in order to forestall scramble for arbitrary share of portions of inheritance. Rich Muslims whose legal heirs are also rich should endeavour to make bequests to poor non-legal heirs in the society. Bequests can also be made for endowment and other humanitarian services.

Muslims should use all legal means to agitate that Islamic law of wills and inheritance remains the only binding principle of succession for Muslims, and a choice permissible for non-Muslims who want to adopt it as a tool for eradicating poverty in the society. 


\section{References}

Abid H. (2012). The Islamic Wills. Retrieved on January 1, 2012 from http://www.dsssfwills. Stateper.us

Adeniji, K. (2006). Effects of Poverty on National Development. NIJOLATES. Vol. 4 No. 1. Remo Prints and Publications.

Adeniji L.A.A.(2002). The Comparative Study of Inheritance in Islam and Yoruba Traditional Religion, Ibadan: Jilat Publishing Company

Ajakaiye D. \& Adeleye V. (2001). Concept, Measurement and Causes of Poverty. Ibadan C. B. N. Executive Seminar.

Asaf, A. A. F.(1994). Outline of Muhammadan Law. Bombay, Oxford University Press.

Eyijeagbon O. O. (2009). Wills and Survivorships. Retrieved on May 2, 2009 from http://www/oseroghoassociates.com

Fishlow, A. (1995), Inequality, Poverty, and Growth. Washington. The World Bank.

Maulana M. A. (2002). Manual of Hadith. A.A.I.S., Lahore.

Muhammad T. H.(2001). The Noble Quran in the English Language. Dar-us-salam publications, Riyadh, Saudi Arabia.

Nwogugu, E.I. (1990). Family Law in Nigeria, Heinemann, Lagos 